\title{
Central blood pressure and vascular stiffness in Mexican population
}

\section{Presión central aórtica y rigidez vascular en mexicanos}

Jorge E. Cossio-Aranda, Enrique A. Berríos-Bárcenas*, Fernando Rodríguez-Rosales, Nydia Ávila-Vanzinni, Diego Araiza-Garaygordobil, Abelardo Flores-Morales, Nilda Espinola-Zavaleta, Laura Rodríguez-Chávez, Érika Fajardo, Israel Domínguez, Guillermo Fernández-De La Reguera y Juan Verdejo-Paris

Grupo de Estudio de Hipertensión y Mecánica Vascular, Instituto Nacional de Cardiología Ignacio Chávez, Ciudad de México, México

\begin{abstract}
Introduction: Central blood pressure (CBP) is considered a measure of prognostic value for cardiovascular risk. In turn, the aortic pulse wave velocity (PWVAo) and augmentation index (Aix) have been related to arterial stiffness and cardiovascular risk. Controversies exist regarding the reference values in different ethnic groups, ages, and anthropometrics. The objective of this study is to evaluate the CBP and arterial stiffness parameters in a Mexican population by age, gender, and anthropometry. Methods: Between 2015 and 2016, 1009 apparently healthy subjects were recruited in the Instituto Nacional de Cardiología Ignacio Chávez. Using the Arteriograph (TensioMed) equipment with an oscillometric technique, CBP, central pulse pressure (CPP), PWVAo, and Aix were acquired. All results were automatically obtained by computer software version 3.0.0.4. Results: Female sex was prevalent (72\%), mean age was $47 \pm 12$ years; $26 \%$ had normal weight, $43 \%$ were overweight, and $30 \%$ had obesity. The reference values were higher than those reported in other populations. PWVAo and Aix were always found to be higher in females. A central-brachial pressure gradient was observed in $<40$ years with lower CBP. Body mass index (BMI) presented a direct and positive correlation with CBP $(p<0.001)$; however, PWVAo and Aix were not modified. Conclusion: CBP, CPP, PWVAo, and Aix parameters should be considered based on age, gender, and $B M I$. In Mexican population, CBP and CPP values were higher compared with other previously reported values, especially in women, the elderly, and obese. PWVAo and Aix are higher in older women; however, they are not modified by BMI.
\end{abstract}

Key words: Central blood pressure. Aortic pulse wave velocity. Aix aortic. Hispanic. Hypertension.

\section{Resumen}

Introducción: La presión central aórtica (PCA) se considera una medida del valor pronóstico. A su vez, la velocidad de la onda del pulso aórtico (VOPA) y el índice de aumento (IA) se han relacionado con la rigidez arterial y riesgo cardiovascular. Existen controversias sobre los valores de referencia en diferentes grupos. El objetivo de este estudio es evaluar estos parámetros en una población mexicana por edad, género y antropometría. Métodos: Entre 2015 y 2016 se reclutaron 1,009 sujetos aparentemente sanos en el Instituto Nacional de Cardiología Ignacio Chávez. Usando el equipo de Arteriograph (TensioMed) con

Correspondencia:

*Enrique A. Berríos-Bárcenas

E-mail: berrios.md@gmail.com
Disponible en internet: $30-01-2020$ Arch Cardiol Mex. 2020;90(1):21-27 www.archivoscardiologia.com 2604-7063/@ 2019 Instituto Nacional de Cardiología Ignacio Chávez. Publicado por Permanyer. Este es un artículo open access bajo la licencia CC BY-NC-ND (http://creativecommons.org/licenses/by-nc-nd/4.0/). 
técnica oscilométrica, se adquirieron: PCA, presión de pulso central, VOPA e IA. Todos los resultados fueron obtenidos automáticamente. Resultados: El sexo femenino fue prevalente (72\%), edad de $47 \pm 12$ años; $26 \%$ con peso normal, $43 \%$ con sobrepeso y $30 \%$ con obesidad. Todos los valores fueron superiores a los reportados en otras poblaciones. VOPA e IA siempre fueron más altos en mujeres. Se observó un gradiente de presión central-braquial en < 40 años, con menor PCA. El IMC presentó una correlación directa y positiva con la PCA $(p<0,001)$, sin embargo, VOPA e IA no se modificaron. Conclusión: Los parámetros de PCA, VOPA e IA deben considerarse en función de edad, género e IMC. En una población mexicana, los valores de PCA fueron más altos en comparación con informados previamente (Europa y Asia), especialmente en mujeres, ancianos y obesos. VOPA e IA son más altos en mujeres mayores; sin embargo, no son modificados por el IMC.

Palabras clave: Presión central aórtica. Velocidad de onda de pulso aórtico. Índice de aumentación aórtica. Hipertensión.

\section{Introduction}

Central blood pressure (CBP) has been established as a strong predictor of cardiovascular risk. European guidelines for systemic arterial hypertension recognize CBP as a useful tool in the evaluation of treatment, risk stratification, and detection of target organ damage ${ }^{1}$. Likewise, surrogate markers of CBP that translate vascular stiffness, aortic pulse wave velocity (PWVAo), and aortic augmentation index (Aix) have been associated with cardiovascular risk ${ }^{2}$.

However, the measurement of CBP is far from its use in daily clinical practice due to multiple factors including the lack of reference values between individuals of different races, gender, age, and body mass index (BMI).

The objective of this study was to evaluate the CBP, central pulse pressure (CPP), PWVAo, and Aix in a population of healthy Mexican subjects, to identify reference values, and to know their behavior according to gender, age, and BMI.

\section{Methods}

\section{Design and population}

Between 2015 and 2016, an observational cross-sectional study was conducted. The recruitment was done through open invitation to the people who were accompanying patients of the outpatient care department of our institution by convenience. These subjects were asked to fill out a survey and undergo an electrocardiogram to rule out any cardiovascular disease. Those with a history of hypertension, diabetes mellitus, smoking, alcoholism, ischemic heart disease, peripheral vascular disease, and electrocardiographic data of hypertensive heart disease were excluded from the study. A clinical questionnaire was applied and anthropometric measurements of weight in kilograms and height in meters were made to calculate the BMI. Subjects were classified according to their BMI values: underweight $(<18.5)$, normal (18.5-24.9), overweight (25-29.9), obesity Grade 1 (30-34.9), obesity Grade 2 (35-39.9), and obesity Grade $3(\geq 40)$.

\section{Measurement of CBP}

An Arteriograph (TensioMed) device with oscillometric technique was used for its evaluation ${ }^{3}$; the CBP measurements of the subjects were carried out between 9:00 a.m. and 11:00 a.m., on a single occasion, all records were obtained in a quiet environment, after resting in supine position for $5 \mathrm{~min}$ and later analyzed with software (version 3.0.0.4.), which reported CBP, cPP, systolic brachial pressure (SBP), brachial pulse pressure (bPP), PWVAo, and Aix.

\section{Statistical analysis}

The numerical variables are summarized as mean and standard deviation or median and quartiles 25 and 75 , according to their distribution. The categorical variables are summarized in frequency and percentage. We performed bivaried analysis of two independent groups with t-test or Mann-Whitney U-test for numerical variables and Chi-square test for categorical variables. When there are more than two groups to be compared, the ANOVA, Kruskal-Wallis, and Chi-square linear trend tests were used, depending on the case. Bivaried correlations were performed (Pearson or Spearman, according to distribution). Multivariate analysis was performed with logistic regression to predict $\mathrm{CBP}$ $>140 \mathrm{mmHg}$, PWVAo > $9 \mathrm{~m} / \mathrm{s}$, and Aix > 33\% using the Statistical Package for the Social Sciences 22.0, a twotailed $p<0.05$ was considered statistically significant.

\section{Results}

We included 1009 participants, 72\% were female, average age of $47 \pm 12$ years (minimum of 15 , maximum of 89 years), $7 \%$ with active smoking, $26 \%$ with 
Table 1. Central blood pressure and arterial stiffness parameter by sex

\begin{tabular}{|l|c|c|c|c|}
\hline Parameter & Total $(\mathbf{n}=\mathbf{1 0 0 9})$ & Female $(\mathbf{n}=\mathbf{7 2 7})$ & Male (n= 282) & p-value \\
\hline Age in years & $47 \pm 12$ & $48 \pm 12$ & $46 \pm 13$ & NS \\
\hline BMI $\left(\mathrm{kg} / \mathrm{m}^{2}\right)$ & $27(24-30)$ & $27(24-31)$ & $27(24-30)$ & NS \\
\hline SBP $(\mathrm{mmHg})$ & $126(117-139)$ & $126(117-141)$ & $129(119-139)$ & NS \\
\hline bPP $(\mathrm{mmHg})$ & $53 \pm 10$ & $54 \pm 11$ & $52 \pm 9$ & 0.001 \\
\hline CBP $(\mathrm{mmHg})$ & $126(113-141)$ & $127(113-143)$ & $124(111-138)$ & 0.03 \\
\hline CPP $(\mathrm{mmHg})$ & $53 \pm 14$ & $54 \pm 14$ & $47 \pm 12$ & $<0.001$ \\
\hline PWVAo (m/s) & $7.8(6.9-9.3)$ & $7.9(7-9.7)$ & $7.6(6.8-8.5)$ & $<0.001$ \\
\hline Aix $(\%)$ & $33 \pm 13$ & $36 \pm 13$ & $27 \pm 13$ & $<0.001$ \\
\hline Arterial age & $40 \pm 16$ & $41 \pm 16$ & $38 \pm 15$ & 0.001 \\
\hline
\end{tabular}

BMI: body mass index; SBP: systolic brachial blood pressure; bPP: brachial pulse pressure; CBP: central blood pressure; cPP: central pulse pressure; PWVAo: aortic pulse wave velocity; Aix: augmentation index. Variables are summarized as mean and standard deviation or median and quartiles 25 and 75 , according to their distribution.

normal weight (BMI in the whole population: $28 \pm$ $\left.4.6 \mathrm{~kg} / \mathrm{m}^{2}\right), 43 \%$ overweight, $22 \%$ obesity Grade 1, $6 \%$ obesity Grade 2, and 2\% obesity Grade 3.

\section{Analysis by sex}

Table 1 shows the results divided by sex. There were no differences in age, BMI, or brachial systolic blood pressure. However, women had higher levels of CBP and $\mathrm{CPP}$, with higher proportions with $\mathrm{CBP}$ above the expected limit, without statistical significance (> $140 \mathrm{mmHg}, 29 \%$ vs. $23 \%, p=0.056$ ). At the same time, women had significantly higher values of PWVAo and Aix. Similarly, the calculated arterial age was higher for women, despite similar chronological ages. When taking the CBP cutoff points $\geq 140 \mathrm{mmHg}$ and cPP $\geq 50 \mathrm{mmHg}$ for the diagnosis of high blood pressure, a higher proportion of new diagnoses was observed in women, without observing important changes in men or when using brachial measurements (Fig. 1).

\section{Analysis by age}

Table 2 shows the measurements obtained by age group. We observed a moderate direct association between age and SBP (rho $=0.34, p<0.001$ ), which improves for CBP $(r=0.47, p<0.0001)$ and $c P P(r=0.49$, $p<0.0001)$. Two other phenomena were observed: the first, in subjects younger than 40 years, a significant gradient between SBP and CBP is observed, after this age, the pressures are similar (Fig. 2). Second, women under 40 years have lower values of CBP; however,

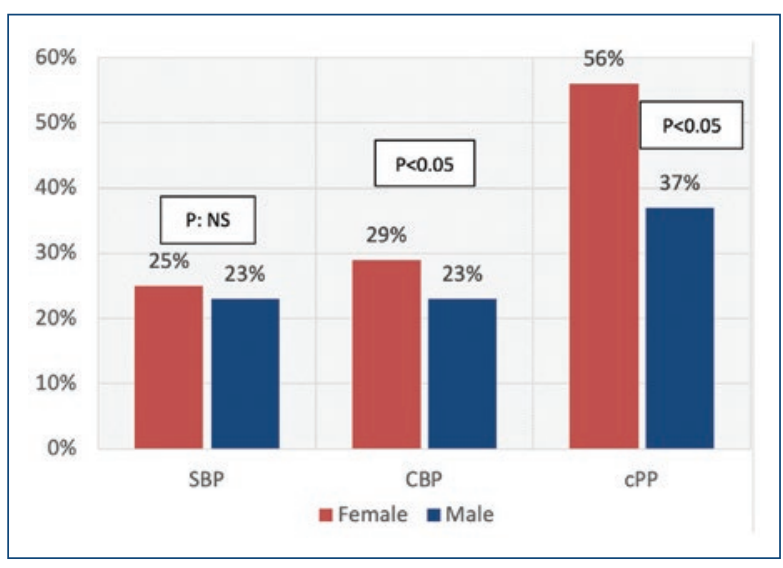

Figure 1. New diagnoses of high blood pressure. Red bar represents female. Blue bars represent male. With SBP, similar proportion of new high blood pressure diagnosis was made. With CBP, a higher proportion of high blood pressure new diagnosis in female was observed. The proportion is higher with cPP. SBP: systolic brachial blood pressure; CBP: central blood pressure; $C P P$ : central pulse pressure.

when this age is exceeded, CBP exceeds men (Fig. 3). Regarding the parameters of vascular rigidity, both have moderate direct association with age $(r=0.52, p<0.001$ for PWVAo and $r=0.57, p<0.001$ for Aix). Regardless of age, women have higher Aix values.

\section{BMI analysis}

Table 3 shows the measurements by weight category. Weak direct associations were observed between BMI, 
Table 2. Central blood pressure and arterial stiffness parameter by age

\begin{tabular}{|c|c|c|c|c|c|c|c|}
\hline Parameter & $<30 \mathrm{a}(\mathrm{n}=95)$ & $30-39 a(n=156)$ & $40-49 a(n=286)$ & $50-59 a(n=285)$ & $60-69 a(n=150)$ & $>70 \mathrm{a}(\mathrm{n}=37)$ & p-value \\
\hline BMI $\left(\mathrm{kg} / \mathrm{m}^{2}\right)$ & $24(25-28)$ & $27(25-31)$ & $27(25-31)$ & $27(25-31)$ & $27(24-30)$ & 27 (26-29) & $<0.001$ \\
\hline SBP $(\mathrm{mmHg})$ & $120(112-126)$ & $121(115-130)$ & $124(117-137)$ & $129(120-144)$ & 138 (124-152) & $142(130-165)$ & $<0.001$ \\
\hline bPP (mmHg) & $52(45-59)$ & $49(44-56)$ & $51(44-57)$ & 52 (46-59) & $58(50-56)$ & 63 (52-74) & $<0.001$ \\
\hline $\mathrm{CBP}(\mathrm{mmHg})$ & $109(103-118)$ & 114 (107-128) & $124(113-137)$ & $131(120-149)$ & 140 (127-156) & 145 (135-168) & $<0.001$ \\
\hline cPP $(\mathrm{mmHg})$ & $42(38-45)$ & $43(38-50)$ & $48(42-58)$ & $54(45-63)$ & $63(52-71)$ & 69 (57-79) & $<0.001$ \\
\hline PWVAo (m/s) & $6.3(6-6.9)$ & $7.1(6.4-7.6)$ & $7.6(7-8.3)$ & $8.4(7.5-10)$ & $9.7(8.3-11)$ & $10.5(8.7-11)$ & $<0.001$ \\
\hline Aix $(\%)$ & $18(11-24)$ & $24(15-32)$ & 31 (23-39) & $39(31-46)$ & $44(35-52)$ & $47(37-53)$ & $<0.001$ \\
\hline Arterial age & $18(15-27)$ & 31 (18-38) & $38(30-46)$ & $47(38-60)$ & $60(46-60)$ & $60(51-60)$ & $<0.001$ \\
\hline
\end{tabular}

BMI: body mass index; SBP: systolic brachial blood pressure; bPP: brachial pulse pressure; CBP: central blood pressure; cPP: central pulse pressure; PWVAo: aortic pulse wave velocity; Aix: augmentation index. Variables are summarized as median and quartiles 25 and 75, according to their distribution.

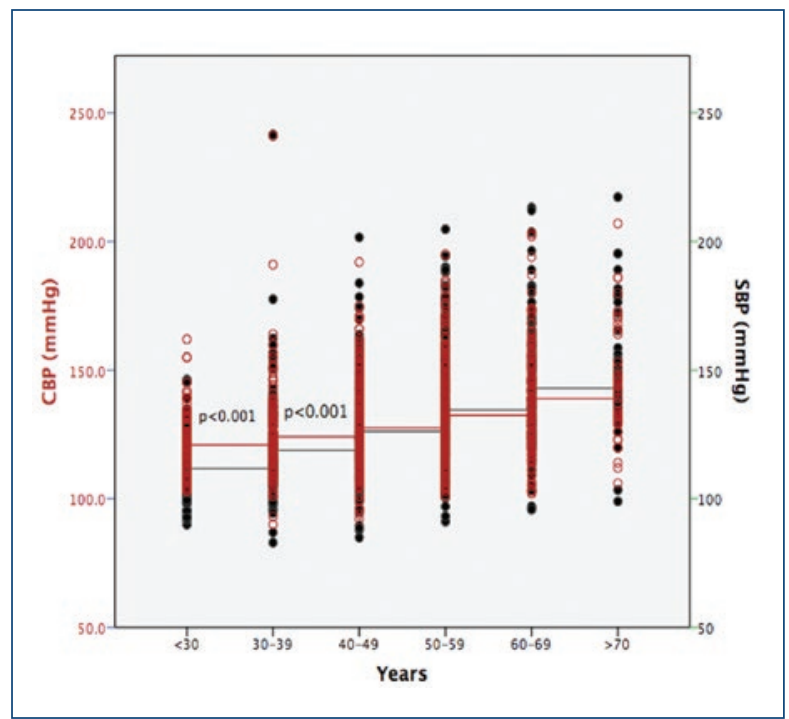

Figure 2. Gradient between CBP and SBP by age. Black circles represent SBP. Red circles represent CBP. There is a significant gradient CBP-SBP before 40 years. After this age, CBP and SBP are similar. SBP: systolic brachial blood pressure (black circles); CBP: central blood pressure (red circles).

SBP (rho $=0.24, p<0.001$ ), and CBP (rho $=0.19$, $p<0.001)$; however, the values of these last two increase to a greater degree of obesity in a significant way. When analyzing vascular rigidity parameters, no association with BMI is observed.

\section{Logistic regressions}

Table 4 shows logistic regressions. Independent predictors for $\mathrm{CBP}>140 \mathrm{mmHg}$ are age and $\mathrm{BMl}$ and for PWVAo $>9 \mathrm{~m} / \mathrm{s}$ and Aix $>33 \%$ are age and sex,

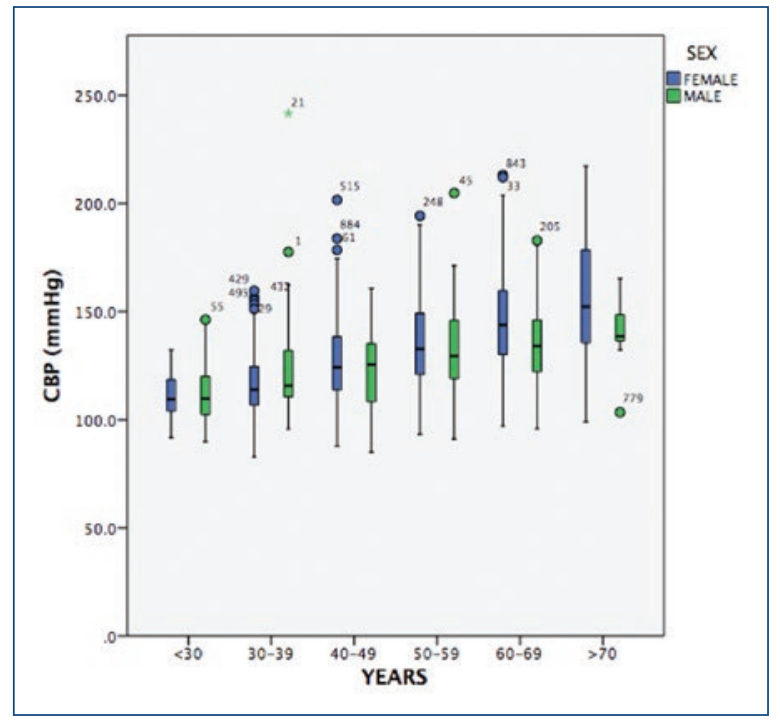

Figure 3. CBP by age and sex. The blue box plots represent CBP in females. The green box plots represent CBP in males. Notice similar values between females and males before 40 years. After 40 years, CBP is higher in female subjects. CBP: central blood pressure.

without showing effect by the BMI on these parameters related to vascular stiffness.

\section{Discussion}

Central aortic pressure has been established as a reliable measure for the stratification of prognosis and cardiovascular risk. Its elevation has been correlated with the thickness of the intima-media of the carotids ${ }^{4}$, increase and regression of left ventricular mass in hypertensive patients ${ }^{5}$, and with a better ability to predict 
Table 3. Central blood pressure and arterial stiffness parameter by BMI

\begin{tabular}{|l|c|c|c|c|c|c|}
\hline Parameter & $\begin{array}{c}\text { Normal } \\
(\mathbf{n}=\mathbf{2 6 4})\end{array}$ & $\begin{array}{c}\text { Overweight } \\
(\mathbf{n}=\mathbf{4 4 1})\end{array}$ & $\begin{array}{c}\text { Obesity Grade } \mathbf{1} \\
\mathbf{( n = 2 2 8})\end{array}$ & $\begin{array}{c}\text { Obesity Grade } \mathbf{2} \\
(\mathbf{n}=\mathbf{5 7})\end{array}$ & $\begin{array}{c}\text { Obesity Grade 3 } \\
(\mathbf{n}=\mathbf{1 9})\end{array}$ & $\mathbf{p}$-value \\
\hline Age by years & $46(33-57)$ & $49(41-57)$ & $49(40-57)$ & $48(42-55)$ & $48(43-56)$ & 0.003 \\
\hline SBP (mmHg) & $124(114-133)$ & $125(117-138)$ & $130(12-144)$ & $143(124-154)$ & $143(129-159)$ & $<0.001$ \\
\hline bPP (mmHg) & $51(44-57)$ & $51(45-58)$ & $54(48-61)$ & $60(53-65)$ & $60(52-73)$ & $<0.001$ \\
\hline CBP (mmHg) & $121(109-136)$ & $125(112-141)$ & $128(115-145)$ & $142(124-155)$ & $139(132-162)$ & $<0.001$ \\
\hline CPP (mmHg) & $48(41-60)$ & $49(42-60)$ & $51(43-63)$ & $59(51-69)$ & $59(50-69)$ & $<0.001$ \\
\hline PWVAo (m/s) & $7.7(6.7-9.4)$ & $7.8(6.9-9.4)$ & $7.9(7-9.2)$ & $8(7.2-9.5)$ & $8.2(7.5-9.2)$ & 0.42 \\
\hline Aix (\%) & $33 \pm 14$ & $33 \pm 13$ & $32 \pm 13$ & $34 \pm 12$ & $35 \pm 13$ & 0.79 \\
\hline Arterial age & $39(24-60)$ & $41(29-60)$ & $42(30-60)$ & $43(33-60)$ & $45(37-60)$ & 0.27 \\
\hline
\end{tabular}

BMI: body mass index; SBP: systolic brachial blood pressure; bPP: brachial pulse pressure; CBP: central blood pressure; cPP: central pulse pressure; PWVAo: aortic pulse wave velocity; Aix: augmentation index. Variables are summarized as mean and standard deviation or median and quartiles 25 and 75 , according to their distribution.

Table 4. Logistic regressions

\begin{tabular}{|l|c|c|}
\hline Parameter & OR (CI 95\%) & p-value \\
\hline $\begin{array}{l}\text { To predicts CBP }>140 \mathrm{mmHg} \\
\text { Age by years }\end{array}$ & $1.08(1.06,1.1)$ & $<0.0001$ \\
\hline BMI $\left(\mathrm{K} / \mathrm{m}^{2}\right)$ & $1.09(1.05,1.13)$ & 0.001 \\
Male sex & $0.8(0.5,1.1)$ & $\mathrm{NS}$ \\
\hline To predicts PWVAo $>9 \mathrm{~m} / \mathrm{s}$ & & \\
Age by years & $1.12(1.1,1.14)$ & $<0.0001$ \\
BMI $\left(\mathrm{k} / \mathrm{m}^{2}\right)$ & $1(0.9,1.03)$ & $\mathrm{NS}$ \\
\hline Male sex & $0.36(0.24,0.54)$ & $<0.0001$ \\
\hline To predicts Aix $>33 \%$ & & \\
Age by years & $1.11(1.09,1.13)$ & $<0.0001$ \\
\hline BMI $\left(\mathrm{k} / \mathrm{m}^{2}\right)$ & $0.97(0.94,1)$ & $\mathrm{NS}$ \\
Male sex & $0.25(0.18,0.36)$ & $<0.0001$ \\
\hline
\end{tabular}

BMI: body mass index; CBP: central blood pressure; PWVAo: aortic pulse wave velocity; Aix: augmentation index.

cardiovascular events compared to brachial blood pressure $^{2}$. Similarly, the cPP $\geq 50 \mathrm{mmHg}$ is associated with morbi-mortality ${ }^{1}$.

However, the measurement of CBP in daily clinical practice is far from being a reality, for a variety of reasons. Among them, the multitude of equipment available for measurement, the lack of normal reference values for particular populations (such as Hispanics) and of reference tables in patients according to age, sex and body weight ${ }^{6}$.

In addition, the evidence regarding CBP in relation to cardiovascular risk is not conclusive since it mostly comes from subanalysis, with sometimes contradictory results. Therefore, although it shows a promising role in the non-invasive stratification of risk, CBP has not succeeded in replacing brachial measurements in the diagnosis, follow-up, and prognosis of patients with systemic arterial hypertension.

The present study tries to solve, in part, the problem described above, delimiting the normal values of reference in healthy Hispanic population (which in itself presents a higher cardiovascular risk than other races) and with the use of equipment widely validated in the previous studies, with the objective of establishing a base in the area of research on central aortic pressure in Mexican population.

\section{CBP and gender}

Regarding the relationship between CBP and sex, a statistically significant difference was observed between men and women, however, with a delta of only $3 \mathrm{mmHg}$. Studies with a large number of patients in China and Europe showed similar results ${ }^{7,8}$. It is noteworthy that, after 40 years of age, the CBP is equal and even, when over 60 years old, the gradient is reversed and becomes greater for women than men.

Notably, the use of CBP and its measurements increased the proportion of women with a new diagnosis of hypertension, but not with the use of SBP. According to data from ENSANUT 2016, the prevalence in Mexico of hypertension is $25.5 \%$, and $40 \%$ do not know its diagnosis ${ }^{9}$. The greater proportion of new diagnoses in women is due to the effect of the use of CBP, despite the fact that SBP values were similar.

When comparing the reference values of our population with European and Asian results, higher values were found $d^{7,8}$. These results are relevant because they may 
be associated with a higher baseline cardiovascular risk in Hispanics, according to previously reported ${ }^{10}$.

Regarding the CPP and Aix, women presented higher statistically significant values, however, directly influenced by the height, a finding already described previously ${ }^{11}$. However, the PWVAo (which is not modified by the height) is elevated in women, probably in relation to greater vascular rigidity. Although our results cannot be conclusive in this regard, we believe that they support the hypothesis that women may present different risk and pathophysiology, so they may also need special considerations in treatment.

\section{CBP and age}

The increase in age leads to an increase in CBP and vascular rigidity parameters. This association has been reproduced by various publications ${ }^{7,8,12}$, which is reflected in the higher prevalence of hypertension as the age advances ${ }^{13}$.

Of relevance, a statistically significant gradient of central-brachial pressure was observed in patients under 40 years of age. After this age, the significance is lost and both pressures present similar measurements. Our results show CBP values of 109 (103-118) and 114 (107-128) mmHg in < 30 and $30-40$ years, respectively, and a central-brachial gradient of 11 and $7 \mathrm{mmHg}$ was observed and may consider normal.

The significance of the loss of this gradient or the presence of higher CBP values in this age group and its relationship with an increased risk of arterial hypertension remains to be clarified. Saladini et al. ${ }^{14}$ recruited 305 patients with an age of $37 \pm 10$ years and performed measurements of SBP and CBP, finding this central-brachial gradient; at follow-up, subjects with a lower gradient had a higher incidence of high blood pressure. Therefore, the measurement of CBP could have a potential impact on the early diagnosis of high blood pressure in subjects less than 40 years.

\section{$C B P$ and $B M I$}

Regarding the BMI, it was found that the greater the degree of obesity, there is an increase in the CBP and the brachial measurements, data observed in previous publications ${ }^{15,16}$. However, the parameters of vascular rigidity did not show differences between the degrees of obesity. Other authors have reported this finding ${ }^{15-17}$, suggesting that different physiopathological mechanisms are present in the patient with obesity. Messerli et al. ${ }^{18}$ conducted a study to assess the hemodynamic differences associated with hypertension and obesity, reporting that the total blood volume is significantly increased in obese hypertensive patients and found no differences in peripheral resistance or plasma renin activity. The same author later published that obese subjects had lower values of circulating catecholamines when compared with subjects of normal weight ${ }^{19}$. These data suggest that, at least partially, a cause of arterial hypertension in obese patients is the increase in blood volume and not an effect of vascular rigidity or catecholamines so that treatments should possibly be aimed at this objective.

\section{Conclusion}

We observe significant differences in CBP, cPP, PWVAo, and Aix based on age, gender, and BMI. In a Mexican population, higher values of CBP and CPP were found in female, the elderly, and obese, with a central-brachial gradient in younger than 40 years. PWVAo and Aix are high in women and the elderly; however, they are not modified by BMI.

\section{Limitations}

The main limitations of our study are the sample size, although, to our current knowledge, it could be the largest Hispanic population included in this issue. On the other hand, the lack of follow-up and hard outcomes makes it difficult to relate our findings to risk, so additional studies are needed to clarify the role of CBP and the parameters of vascular rigidity in the stratification and diagnosis of hypertension in Hispanics. Our study included a greater proportion of female sex because socially in our environment is this gender the natural companion of patients to their medical consultations; this could have an impact on the generalization of the results, mainly in the differences by gender.

\section{Conflicts of interest}

None declared.

\section{Funding}

None.

\section{Responsabilidades éticas}

Protección de personas y animales. Los autores declaran que para esta investigación no se han realizado experimentos en seres humanos ni en animales. 
Confidencialidad de los datos. Los autores declaran que han seguido los protocolos de su centro de trabajo sobre la publicación de datos de pacientes.

Derecho a la privacidad y consentimiento informado. Los autores declaran que en este artículo no aparecen datos de pacientes.

\section{References}

1. Safar ME, Jankowski P. Central blood pressure and hypertension: role in cardiovascular risk assessment. Clin Sci (Lond). 2009;116:273-82.

2. Roman MJ, Devereux RB, Kizer JR, Lee ET, Galloway JM, Ali T, et al. Central pressure more strongly relates to vascular disease and outcome than does brachial pressure: the strong heart study. Hypertension. 2007 50:197-203.

3. Horváth IG, Németh A, Lenkey Z, Alessandri N, Tufano F, Kis P, et al. Invasive validation of a new oscillometric device (Arteriograph) for measuring augmentation index, central blood pressure and aortic pulse wave velocity. J Hypertens. 2010;28:2068-75.

4. Boutouyrie P, Bussy C, Lacolley P, Girerd X, Laloux B, Laurent S. Association between local pulse pressure, mean blood pressure, and large-artery remodeling. Circulation. 1999;100:1387-93.

5. Roman MJ, Okin PM, Kizer JR, Lee ET, Howard BV, Devereux RB. Relations of central and brachial blood pressure to left ventricular hypertrophy and geometry: the strong heart study. J Hypertens. 2010;28:384-8.

6. McEniery CM, Cockcroft JR, Roman MJ, Franklin SS, Wilkinson IB. Central blood pressure: current evidence and clinical importance. Eur Heart J. 2014;35:1719-25.

7. Fu S, Luo L, Ye P, Liu Y, Zhu B, Zheng J, et al. Overall and abdominal obesity indicators had different association with central arterial stiffness and hemodynamics independent of age, sex, blood pressure, glucose, and lipids in Chinese community-dwelling adults. Clin Interv Aging. 2013; 8:1579-84.
8. Herbert A, Cruickshank JK, Laurent S, Boutouyrie P, Reference Values for Arterial Measurements Collaboration. Establishing reference values for central blood pressure and its amplification in a general healthy population and according to cardiovascular risk factors. Eur Heart J. 2014;35:3122-33

9. Available from: http://www.promocion.salud.gob.mx/dgps/descargas1/ doctos 2016/ensanut mc 2016-310oct.pdf.

10. Daviglus ML, Pirzada A, Talavera GA. Cardiovascular disease risk factors in the Hispanic/Latino population: lessons from the Hispanic Community Health Study/Study of Latinos (HCHS/SOL). Prog Cardiovasc Dis. 2014:57:230-6.

11. Hidvégi EV, Illyés $M$, Molnár $F T$, Cziráki A. Influence of body height on aortic systolic pressure augmentation and wave reflection in childhood. J Hum Hypertens. 2015;29:495-501.

12. Mahmood SS, Levy D, Vasan RS, Wang TJ. The Framingham heart study and the epidemiology of cardiovascular disease: a historical perspective. Lancet. 2014;383:999-1008.

13. Benjamin EJ, Blaha MJ, Chiuve SE, Cushman M, Das SR, Deo R, et al. Heart disease and stroke statistics-2017 update: a report from the American Heart Association. Circulation. 2017;135:e146-603.

14. Saladini F, Mos L, Casiglia E, Malipiero G, Mazzer A, Palatini P. Central blood pressure is an independent predictor of future hypertension in young to middle-aged stage 1 hypertensives. Blood Press. 2013;22:9-16.

15. Pichler G Martinez F Vicente A Solaz F Calaforra $O$, Lurbe $E$, et al. Influence of obesity in central blood pressure. J Hypertens. 2015;33:308-13.

16. Kolade OO, O'Moore-Sullivan TM, Stowasser M, Coombes JS, Fassett RG, Marwick TH, et al. Arterial stiffness, central blood pressure and body size in health and disease. Int J Obes (Lond). 2012;36:93-9.

17. Desamericq G, Tissot CM, Akakpo S, Tropeano Al, Millasseau S, Macquin-Mavier I. Carotid-femoral pulse wave velocity is not increased in obesity. Am J Hypertens. 2015;28:546-51.

18. Messerli FH, Christie B, DeCarvalho JG, Aristimuno GG, Suarez DH, Dreslinski GR, et al. Obesity and essential hypertension. Hemodynamics, intravascular volume, sodium excretion, and plasma renin activity. Arch Intern Med. 1981;141:81-5.

19. Messerli FH, Ventura HO, Reisin E, Dreslinski GR, Dunn FG, MacPhee AA, et al. Borderline hypertension and obesity: two prehypertensive states with elevated cardiac output. Circulation. 1982;66:55-60. 